\title{
Fallow Land, Recession and Socio-Demographic Local Contexts: Recent Dynamics in a Mediterranean Urban Fringe
}

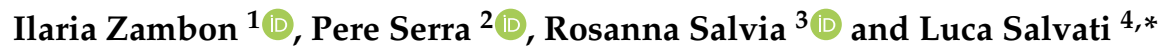 \\ 1 Department of Agricultural and Forestry Sciences, DAFNE Tuscia University, \\ Via San Camillo de Lellis snc, I-01100 Viterbo, Italy; ilaria.zambon@unitus.it \\ 2 Department of Geography, Autonomous University of Barcelona, Building B, \\ Campus UAB, ES-08193 Bellaterra (Cerdanyola del Vallès), Spain; pere.serra@uab.cat \\ 3 Department of Mathematics, Computer Science and Economics, University of Basilicata, \\ Via dell'Ateneo Lucano, I-85100 Potenza, Italy; rosanna.salvia@unibas.it \\ 4 Council of Agricultural Research and Economics (CREA), Research Centre for Forestry and Wood, \\ Viale S. Margherita 80, I-52100 Arezzo, Italy \\ * Correspondence: luca.salvati@crea.gov.it; Tel.: +06-7005413
}

Received: 21 August 2018; Accepted: 8 October 2018; Published: 11 October 2018

\begin{abstract}
Urban settlements have globally expanded into rural land. Being influenced by complex socio-environmental dynamics and sometimes acting as a reserve of economic value, fallow land has characterized rural areas in a distinctive way over the last decades. The present work debates on the role of fallow land as a component of Mediterranean peri-urban landscapes, considering together different aspects from environmental/agronomic and regional science perspectives. An empirical analysis of the latent relationship between spatial distribution of fallow land, agricultural landscape (land-use, territorial, and topographic characteristics), and urban sprawl was carried out in a representative Mediterranean case study (Athens, Greece) evidencing the possible linkage between urban growth/containment, conservation of rural biodiversity/local traditions, and fallow land (intended as a candidate source of buildable land) in fringe districts. Urban growth at the local scale was contrasted with the spatial distribution of fallow land under sequential expansions and recessions of the regional economic system. Conservation of marginal rural land in fringe districts-including fallow land-is a necessary target of any sustainable land management strategy in metropolitan contexts experiencing rapid socioeconomic transformations.
\end{abstract}

Keywords: agricultural landscape; olive groves; metropolitan area; sustainable land management; Greece

\section{Introduction}

Urbanization-driven land take exerts serious environmental pressures on agricultural landscapes worldwide, particularly in peri-urban areas, and is molded by social forces associated with residential development, demographic change, economic growth, and improvements in infrastructures and transportation. Policy strategies and planning instruments aimed at containing agricultural land consumption usually adopt more or less specific approaches, based on the intimate characteristics of target areas. Zoning approaches may draw on information dealing with land-use transitions and their detrimental role altering the functionality of soils, water balance, or habitat quality at specific locations [1]. Results of earlier studies showed that rapid expansion of built-up areas in metropolitan regions of economically-advanced countries led to accelerated land-use conversion, determining land abandonment and a consequent loss of cropland [2]. 
Transformation of agricultural landscapes are widespread land-use changes in temperate regions, leading to crop intensification (or land abandonment) at certain locations and a growing dependence on other world regions for many agricultural products. Natural conservation policies and socio-demographic transitions leading to accelerated internal migration, e.g., from rural to urban areas, are intrinsic forces contributing to shape such dynamics. The socio-environmental outcomes of land abandonment/recovery and the potential for agricultural intensification (or extensivation) hinge on incomplete knowledge about the spatial patterns of farmland transformations at the regional scale, the related driving forces, and the underlying socioeconomic context at the local scale. A comprehensive assessment of different use of rural land-including abandoned cropland and recovery of previously abandoned farmland-forms a basis for assessing the environmental outcomes of different agricultural practices and the potential of unused land for food production, bioenergy, and carbon storage [3-9], also evidencing the role of imperfect local markets, technological backwardness, farmholder's inaction, and the impact of economic crisis on local agricultural productions.

Fallow land is a specific use of rural land. Being a consolidated and environmentally-friendly agronomic practice, set-aside is sometimes associated with specific cropland (e.g., cereals) and defined characteristics of entrepreneurs. Set-aside land was shown to be an effective way to improve soil chemistry and increase biodiversity on arable farmland. In this regard, as a result of set-aside practices, fallow land is commonly defined as a farmland ploughed and harrowed but left for a period without being sown - to restore its fertility or to avoid surplus production. Set-aside has been extensively subsidized within the European Union (EU) Common Agricultural Policy framework. Subsidies to set-aside were introduced by the European Economic Community in 1988 (Regulation No. 1272/88), with multiple objectives dealing with both economic targets and environmental benefits-following considerable damage to agricultural ecosystems and wildlife as a result of the intensification of many agricultural systems. Set-aside became compulsory in 1992 for large arable farmers as part of the MacSharry reform of the Common Agricultural Policy. The European Commission reduced the set-aside requirement to $0 \%$ in 2008, agreeing to abolish set-aside through the Common Agricultural Policy (CAP) Health Check.

In a continuous effort to make agriculture more environmentally-friendly and socially sustainable, agri-environmental schemes have been introduced as part of European Union's (EU) Common Agricultural Policy and are now a key issue in any strategy of rural development [10]. Methodological approaches to analyze agri-environmental schemes include the use of specific indicators of rural development, concentrating on sustainable agronomic practices and land-use. The ratio of fallow land in total arable land or in total utilized agricultural area is considered a relevant agri-environmental indicator, and a higher percentage of fallow land in a rural landscape may reflect (more or less intense) processes of agricultural extensivation, contributing to distinguishing "performance" effects (e.g., agricultural practices) from "outcome" effects (e.g., environmental impacts) under specific subsidy regimes. Change in the extent of fallow land is considered an implicit indicator of land-use intensity at the regional scale [10]. Diachronic agri-environmental indicators evaluating trends over time in fallow land at farm and district (i.e., local) scale also provide basic information on change (or maintenance) of traditional land-use and place-based agricultural management practices.

While the extent of fallow land is particularly high in traditional farming systems-especially under poorly or moderately fertile soils and at higher elevation (mountain or upland districts) - fallow land are also relatively common in peri-urban contexts. In this regard, subsidies to set-aside and other economic incentives to ecologically-friendly agronomic practices are considered particularly important in fragmented environments typical of metropolitan regions where relevant land-use conflicts exist and consolidate over time (e.g., thanks to the expansion of both residential and service settlements). Experiencing opportunities and constraints typical of fringe districts, peri-urban farms are increasingly required to cope with both economic targets (i.e., improving agricultural productions in both quantitative and qualitative terms) and environmental targets (e.g., providing ecosystem 
services for local communities and the surrounding cities), in a context where pressure for land is particularly high (driven by real-estate speculation and planning deregulation) and where fertile soils are progressively abandoned thanks to latent socioeconomic forces underlying urban sprawl.

A sustainable land management strategy for metropolitan regions is increasingly required to quantify long-term and short-term land-use changes, identifying trends in relevant driving factors [11-13], with special regard for cropland-being largely consumed by urban expansion. Due to multifaceted social processes, landscape transformations in advanced economies involve several interacting actors [14]. Since the early 1980s, European Mediterranean cities have experienced a rapid transition from mostly compact and dense models to various steps of a more discontinuous morphology characterized by huge expansion around inner cities [15]. Trends toward "compact growth" observed up to the early 1990s and the following "discontinuous urbanization" have affected land-use structure and peri-urban farming in a different way [16], reflecting a spatially-varying rate of land consumption and high impact on specific cropping systems. How the changing use of land represents a target for policies mitigating soil consumption has been discussed in earlier studies, e.g., [17]. However, empirical evidence from different socioeconomic contexts is still necessary to identify the latent relationship between urban growth, peri-urban farming and transformation of rural landscapes in Mediterranean fringes.

Based on these premises, fallow land dynamics over a relatively long time period characterized by different subsidies' regimes-together with basic information on total cropland increase or decline-was considered a useful indicator to infer latent transformations in peri-urban landscapes and to propose strategies that may promote peri-urban agriculture and/or preserve relict cropping systems. While being largely influenced by the related subsidies' regime, fallow land is considered an element of peri-urban landscapes possibly associated with specific characteristics of the regional economic structure and the local community. In such contexts, it was hypothesized that fallow land increased in size over the study period together with direct payments to farmers (EU subsidies), declining more or less rapidly in the most recent transitional phase of rural development, with subsidies oriented mostly to fulfil environmental targets. Our work added to this assumption hypothesizing that fallow land is (i) an additional stock of economic value (depending on the intensity of land speculation and the flexibility of regional planning systems, allowing —or preventing-change in zoning rules that authorize conversion to urban use), or (ii) a stock of rural land immediately available for crop intensification. Considering the transition from economic expansion to crisis, the present work focuses on the Athens metropolitan region (Greece), investigating regional-scale cropland dynamics and long-term trends in fallow land area in a peri-urban landscape dominated by traditional crops-mainly olive-and progressively threatened by urban sprawl. A spatially-explicit analysis of the distribution of fallow land at municipal scale complemented this work, analyzing the background socioeconomic context at the same spatial scale as a possible factor of landscape change. Athens was regarded as a paradigmatic Mediterranean city [18-20], with long-term development processes being representative of both "compact" and "dispersed" waves of urban expansion [21-26]. By considering fallow land together as a proxy of agricultural intensification/extensivation and as an indirect indicator for the increasing pressure of real estate speculation on rural land, our study sheds further light on latent processes of urban growth and agricultural recovery/decline at the fringe of a large Mediterranean city over sequential economic expansions and recessions. In this regard, economic downturns may shape the socioeconomic context, influencing rural land-use and farmland characteristics in a different way, e.g., stimulating rural land-use over time periods when building activity is depressed thanks to economic crisis. Empirical findings of this study may provide a relevant knowledge base to understanding latent mechanisms of landscape transformation in other European contexts with similar ecological and territorial characteristics. 


\section{Materials and Methods}

\subsection{Study Area}

According to the standardized definition of metropolitan areas in Europe proposed by the Urban Atlas initiative [27,28], the Athens' metropolitan region was selected as the study area [26]. This area extends nearly $3000 \mathrm{~km}^{2}$ and coincides with a large part of the administrative region of Attica, central Greece (Figure 1). The area is administered by 114 municipalities classified as urban $(n=58$, coinciding with the Greater Athens' area) or rural ( $n=56$, forming a district called "rural Attica" in this study) and belonging to one of the four Attica prefectures: Athens, Eastern Attica, Western Attica, and Piraeus [29]. The study area consists mainly of mountains bordering the flat district of Athens and three coastal plains (Messoghia, Marathon, and Thriasio) [30]. The prevailing climate regime is Mediterranean dry, with annual rainfall ranging between 350 and $700 \mathrm{~mm}$ and annual average air temperatures around 17-19 ${ }^{\circ} \mathrm{C}$. Although being traditionally devoted to Mediterranean crops (olive trees and vineyards), the region underwent a massive urban expansion in the last two centuries [31,32]. The area is the most densely populated in Greece (more than 4400 inhabitants $/ \mathrm{km}^{2}$ in 2011) and population density has increased nearly 2900 inhabitants $/ \mathrm{km}^{2}$ between 1951 and 2011 . Since the early 1980s, the area experienced suburbanization with a progressive expansion of discontinuous fringe settlements [22]. Rural districts of Messoghia and Thriasio were especially involved in a subtle process of metropolitan expansion driven by real estate speculation and public/private investments during the Olympic Decade [23]. Since the late 2000s, Attica has experienced an intense economic recession [25,33]. Combined with austerity urbanism and neoliberal policy reforms, recession determined diffused unemployment and job insecurity, income decline, poverty and social unrest [34,35]. As a side effect of recession, moderate counter-urbanization was observed, fueling "back-to-the-land" social movements [36].
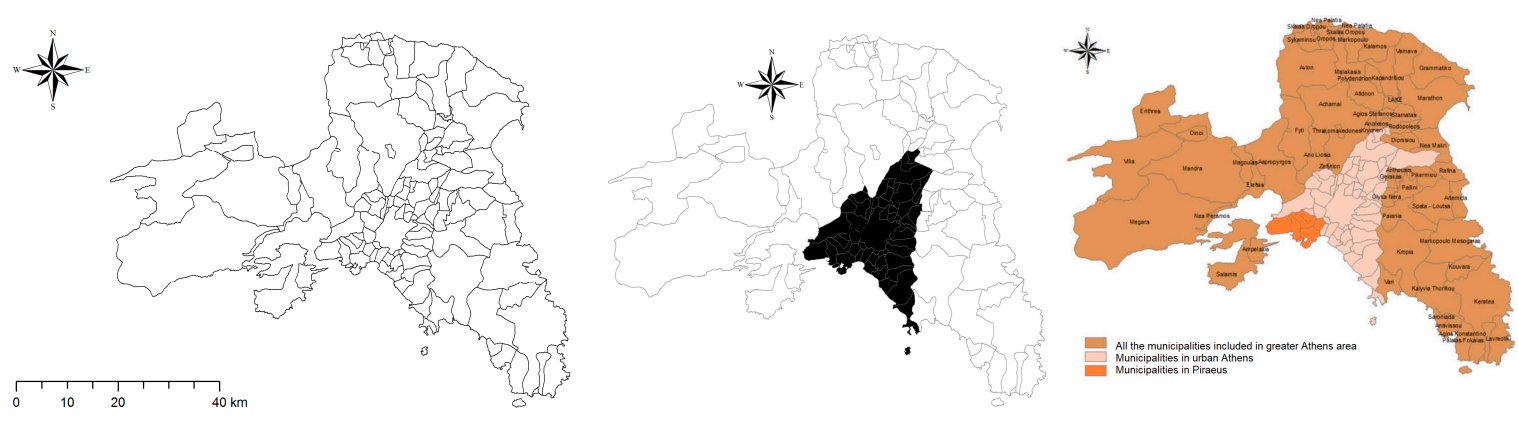

Figure 1. A map illustrating the geography of the study area: municipal boundaries of the study area (left); municipalities classified as urban (black) and rural (center); and geographic divisions (right).

\subsection{Land-Use Indicators}

Statistical data aggregated at the prefectural or regional scale were considered to assess the distribution of different types of cropland in the Greater Athens' area, rural Attica, Attica as a whole, and Greece between 1970 and 2015. Municipalities were selected as the elementary spatial domain for more detailed analysis over a shorter time interval (1993-2015). Information on the dominant agricultural land-use at the municipal scale were derived from official statistics provided by a comprehensive agricultural survey held every year in Greece by the Hellenic Statistical Authority (hereafter ELSTAT) and quantifying land-use (annual crop, tree crop, and fallow land) at the municipal scale since 1993. This data source may provide a comprehensive outlook of recent transformations of the agricultural landscape in the area, giving specific information on rural land-use and the main agricultural practices. Two indicators (utilized agricultural area in total municipal area and fallow land in total agricultural land) were calculated at the selected spatial scale and at three different dates (1993, 2006, and 2015) with the aim to define the possible impact of economic expansion (before 2006) 
and recession (after 2006). The percentage of fallow land under economic subsidies (mainly under the European Common Agricultural Policy framework) was also derived from the same statistical source for the year 2015. A map illustrating the progressive loss of cropland from each municipality of the study area was prepared indicating the year when the complete disappearance of agricultural land (e.g., due to urban expansion) was observed. Twelve additional background indicators assessing basic characteristics of the socio-demographic context (population density, forest land in total landscape, per-capita built-up area, distance from Athens, Piraeus, Maroussi, Markopoulo Messoghias, municipal area, per-capita declared income (log-scale), share of inhabitants living and working in the same municipality in total population, share of population residing in the same municipality five years before the census in total population, and share of non-native population born in total resident population) were derived from official statistics mainly based on ELSTAT censuses and public registers.

\subsection{Data Analysis}

The spatial distribution of the adopted indicators was analyzed using maps and descriptive statistics. A non-parametric statistical approach was developed to analyze land-use and background indicators adopted in this paper since most of the variables considered in this study display relevant deviations from normality. A cluster analysis based on a two-way joining procedure was run on two standardized indicators (agricultural utilized area to total municipal area and fallow land to total agricultural utilized area) at three time points $(1993,2006$, and 2015) with the aim to identify similarities and changes in the spatial distribution of total cropland and fallow land over time, contributing to identify latent patterns of rural land-use and farmland transformations. Municipalities were regarded as the elementary analysis' domain. Two-way joining is probably one of the most commonly-used multivariate (non-parametric) techniques under the hypothesis that both cases and variables will simultaneously contribute to the uncovering of meaningful patterns of clusters. Two-way joining analysis produces a graph ordering cases (municipalities) and variables (land-use indicators) based on similarity/dissimilarity patterns. The graph also indicates a standardized score (with zero-average score) for each case and variable using different colors. Such a graph contributes to identifying specific clusters based on similar (negative or positive) scores for a defined group of variables and cases.

The difficulty when interpreting results from this technique may arise from the fact that similarities between different clusters may pertain to (or be caused by) somewhat different subsets of variables, leading to the assumption that the resulting structure (clusters) is, by nature, heterogeneous. To investigate the impact of spatial heterogeneity on clustering structures, a non-parametric correlation analysis based on pair-wise Spearman co-graduation coefficients was run between the land-use indicators mentioned above and a set of background indicators at the same spatial scale (municipalities). Spearman coefficients range between 1 (the highest positive correlation) and -1 (the highest negative correlation) with 0 indicating absence of both linear and non-linear correlation between variables. Significance was tested at $p<0.05$ after Bonferroni's correction for multiple comparisons. Spatial units (municipalities) where cropland disappeared before 1993 (e.g., urban areas, such as the municipalities of Athens and Piraeus) were excluded from both analyses (two-way clustering and Spearman correlations).

\section{Results}

\subsection{Trends over Time in Total Cropland and Basic Classes of Rural Land-Use Including Fallow Land in Attica}

Table 1 illustrates trends over time in total cropland and specific land-use between 1970 and 2015 in the study area, distinguishing urban from rural districts. In the Greater Athens' area-a consolidated urban area around the central cities of Athens and Piraeus-cropland extended $4.2 \%$ of total land in 1970 and declined to $0.1 \%$ in 2006 and 2015. Arable land accounted for $20 \%$ of cropland in 1970 decreasing to around 1\% in mid-2000s. Garden crops decreased considerably (from 39\% to $21 \%$ over the study period); vineyards were relatively stable around $4 \%$, although with a temporary increase to 
$12 \%-13 \%$ in the late 1990 s and mid-2000s. Tree crop increased considerably from $12 \%$ (1970) to $74 \%$ (2015). Percentage of fallow land in total cropland doubled between 1970 and 2006; nearly half of cropland was managed as fallow land in 2006. This percentage declined substantially in the last time interval, reaching $0 \%$ in 2015.

Table 1. Long-term trends in cropland and fallow land by land-use class in various geographic districts, Greece 1970-2015.

\begin{tabular}{|c|c|c|c|c|c|c|c|c|c|c|c|c|}
\hline Year & $\begin{array}{l}\text { Total } \\
\text { Crops }\end{array}$ & $\begin{array}{c}\text { Arable } \\
\text { Land }\end{array}$ & $\begin{array}{c}\text { Garden } \\
\text { Crop }\end{array}$ & Vineyards & $\begin{array}{l}\text { Tree } \\
\text { Crop }\end{array}$ & $\begin{array}{c}\text { Fallow } \\
\text { Land }\end{array}$ & $\begin{array}{l}\text { Total } \\
\text { Crops }\end{array}$ & $\begin{array}{c}\text { Arable } \\
\text { Land }\end{array}$ & $\begin{array}{c}\text { Garden } \\
\text { Crop }\end{array}$ & Vineyards & $\begin{array}{l}\text { Tree } \\
\text { Crop }\end{array}$ & $\begin{array}{c}\text { Fallow } \\
\text { Land }\end{array}$ \\
\hline & \multicolumn{6}{|c|}{ Greater Athens' area } & \multicolumn{6}{|c|}{ Rural Attica } \\
\hline 1970 & 4.2 & 19.9 & 38.6 & 4.4 & 12.3 & 24.8 & 42.5 & 22.0 & 5.4 & 16.6 & 22.8 & 33.2 \\
\hline 1979 & 3.2 & 15.6 & 35.0 & 4.2 & 18.7 & 26.4 & 39.6 & 19.5 & 4.7 & 17.1 & 26.5 & 32.2 \\
\hline 1988 & 2.9 & 12.3 & 28.0 & 3.2 & 16.1 & 40.5 & 38.3 & 18.7 & 6.0 & 15.5 & 29.2 & 30.6 \\
\hline 1997 & 2.2 & 14.6 & 5.6 & 12.0 & 32.1 & 35.6 & 38.0 & 14.6 & 5.6 & 12.0 & 32.1 & 35.6 \\
\hline 2006 & 0.1 & 0.9 & 25.8 & 13.2 & 12.2 & 47.9 & 29.6 & 13.8 & 7.6 & 9.6 & 34.7 & 34.3 \\
\hline \multirow[t]{2}{*}{2015} & 0.1 & 1.3 & 20.5 & 4.3 & 73.9 & 0.0 & 20.2 & 18.5 & 6.0 & 12.2 & 53.2 & 10.0 \\
\hline & \multicolumn{6}{|c|}{ Attica as a whole } & \multicolumn{6}{|c|}{ Greece } \\
\hline 1970 & 28.9 & 22.0 & 5.8 & 16.4 & 22.7 & 33.1 & 30.9 & 61.9 & 2.6 & 5.4 & 16.6 & 13.4 \\
\hline 1979 & 26.9 & 19.4 & 5.2 & 16.9 & 26.4 & 32.1 & 31.0 & 60.0 & 2.8 & 4.8 & 19.6 & 12.8 \\
\hline 1988 & 26.0 & 18.6 & 6.4 & 15.3 & 29.0 & 30.7 & 30.4 & 59.0 & 2.8 & 4.1 & 22.3 & 11.8 \\
\hline 1997 & 25.7 & 14.5 & 5.8 & 12.0 & 31.9 & 35.8 & 29.8 & 57.6 & 3.1 & 3.4 & 24.4 & 11.5 \\
\hline 2006 & 19.8 & 13.8 & 7.7 & 9.5 & 34.7 & 34.3 & 28.5 & 55.3 & 3.0 & 3.4 & 26.9 & 11.4 \\
\hline 2015 & 13.5 & 18.5 & 6.1 & 12.2 & 53.2 & 10.0 & 24.9 & 52.9 & 2.1 & 2.9 & 31.0 & 11.2 \\
\hline
\end{tabular}

Rural Attica experienced a strong decline in total cropland. The percentage of cropland in the total landscape halved during the study period (42.5\% in 1970; $20.2 \%$ in 2015). The proportion of arable land and garden crops in total farmland remained substantially stable over time; vineyards decreased moderately over the same time period. The most relevant changes in the Attica's agricultural landscape involved tree crop, increasing continuously over time from $23 \%$ (1970) to 53\% (2015). Fallow land remained quite stable up to 2006, with proportions in total cropland ranging between $30 \%$ and $36 \%$. In 2015, fallow land accounted for only $10 \%$ of total cropland in rural Attica. Similar dynamics were observed in the whole of Attica. In Greece, cropland decline was relatively milder, moving from $31 \%$ of total land (1970) to $25 \%$ (2015). Being the dominant agricultural land-use in Greece, arable land decreased by nearly 10\% over the study period (from $61 \%$ in 1970 to $52 \%$ in 2015). Garden crops were substantially stable, and vineyards decreased moderately (from 5\% in 1970 to 3\% in 2015). Tree crop increased continuously, passing from 17\% (1970) to 31\% (2015). Finally, fallow land decreased moderately from $13 \%$ (1970) to $11 \%$ (2015) showing a substantial stability between 2006 and 2015. This evidence outlines that decline of fallow land during the last economic recession in Greece was a phenomenon specifically observed in peri-urban areas, and more specifically in the Athens' metropolitan region. This phenomenon was coupled with more general, long-term trends of agricultural extensivation (increase in tree crop, mainly olive) and local-scale specialization.

\subsection{Spatial Distribution of Total Cropland and Fallow Land in Attica}

Figure 2 illustrates the spatial distribution of selected land-use indicators in the study area through maps. A specific district corresponding with the Greater Athens' area was identified where cropland has disappeared before 1993. This area-including the central cities of Athens, Piraeus, and the surrounding municipalities-was heavily urbanized since the early 1950s and reached the highest population concentration in the 1970s (with density approaching 15,000-20,000 inhabitants per $\mathrm{km}^{2}$ ) and the complete saturation of open spaces in the late 1980s. A circular fringe district around the Greater Athens' area was progressively involved in a process of land conversion from agriculture to residential settlements. The left, top map illustrates the progressive disappearance of cropland from fringe municipalities northeast of Athens between 1993 and 2015, including some coastal areas situated in Eastern Attica prefecture further away from Athens (Rafina, Nea Makri). These areas were 
originally devoted to cropland and are well connected to the most traditional agricultural districts of Messoghia and Marathon.

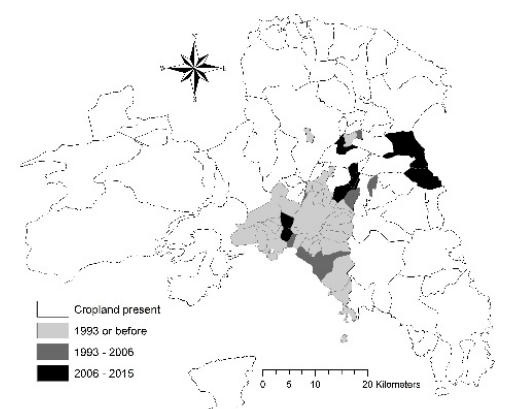

Year of cropland disappearance

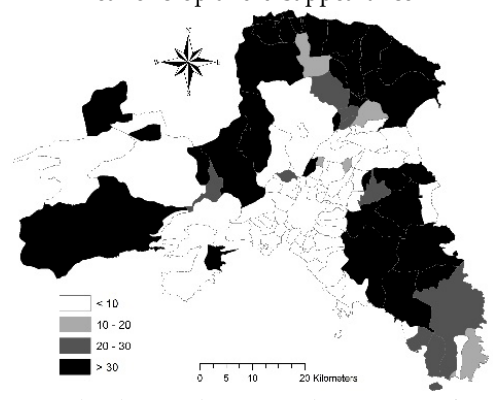

Cropland in total municipal area, 1993 (\%)

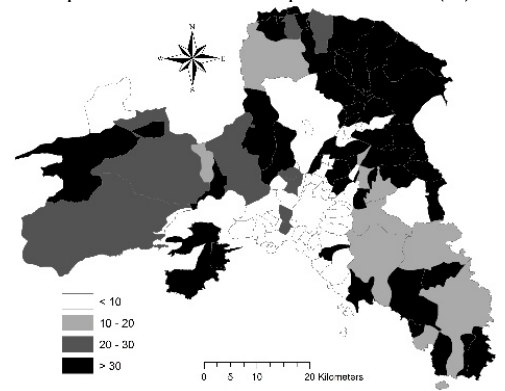

Fallow land in total cropland, 1993 (\%)
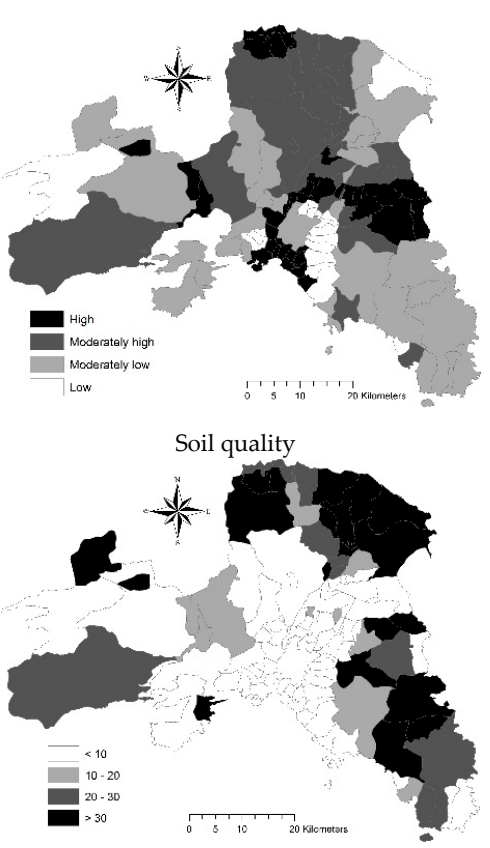

Cropland in total municipal area, 2006 (\%)

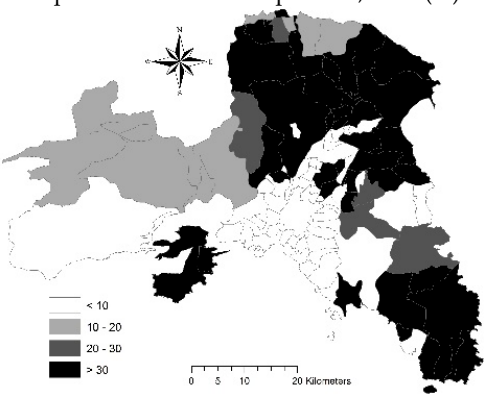

Fallow land in total cropland, 2006 (\%)

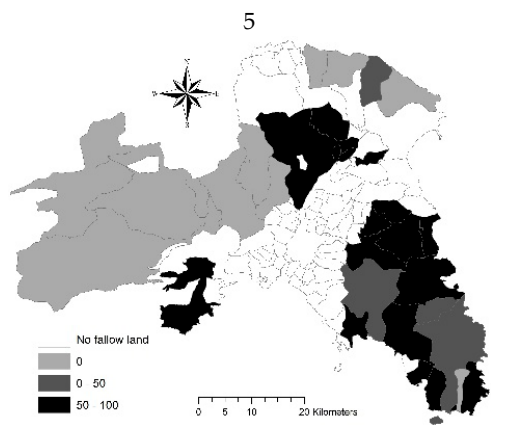

Subsidized land in total fallow land (\%)

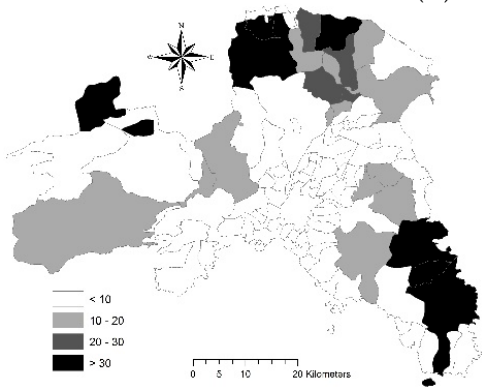

Cropland in total municipal area, 2015 (\%)

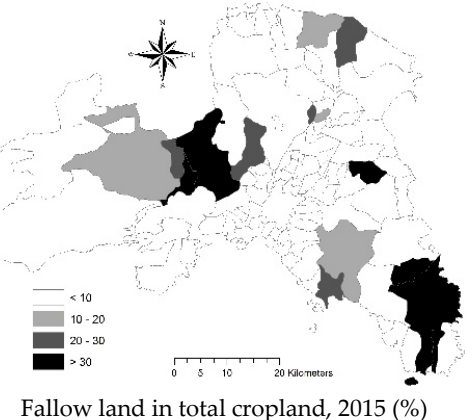

Figure 2. Spatial distribution of selected indicators in the study area.

The spatial distribution of the most stable agricultural areas in the Athens' metropolitan region also reflects soil quality. The lowest proportion of cropland conversion to built-up areas was observed for high- or medium-quality soils, mainly observed in flat districts of Marathon, Messoghia and Keratea (Eastern Attica), Oropos (Northern Attica), and Thriasio/Megara (Western Attica). Thriasio and Megara were districts specialized in traditional cropland (olive, vine, wheat) since antiquity. Cropland in 1993 was characterized by a rather homogeneous, radial distribution around the Greater Athens' area (middle left map). More than 10 years later, cropland declined in Thriasio and Messoghia, two traditional rural districts in Attica particularly exposed to urban sprawl thanks to the infrastructural development typical of the Olympic period (e.g., the new international Airport in Spata and the Attiki motorway in Messoghia, the new railway deposit, and the new national motorway in Thriasio). In 2015, cropland decline was evident in remote rural districts in Northern Attica (Oropos) and Western Attica (Megara). These areas are less exposed to sprawl but relatively well accessible from the central city.

The spatial distribution of fallow land followed only partly the pattern described above for total cropland. In 1993, the highest percentage of fallow land in total cropland was observed in marginal rural districts of Attica (Salamina, Oropos, and Thriasio) and in some fringe municipalities north of Athens (Ano Liosia, Kifissià, Maroussi). Maintaining a stable share in total cropland compared 
with 1993, fallow land concentrated in Salamina Island, Northern Attica (Oropos), and Eastern Attica (Messoghia) in 2006. In the last 10 years, fallow land decreased drastically all over the study area, with the exception of Keratea/Lavrio district, Thriasio plain, and some sparse municipalities in Northern Attica (Oropos) and Messoghia (Koropi, Vari, Spata). The relationship between the percent change over time in total cropland and in fallow land followed a distinct pattern over the two studied intervals (Figure 3). The first-time interval reflects economic expansion (1993-2006) and was characterized by a positive relationship between the two variables (Spearman rank correlation, $\mathrm{r}_{\mathrm{s}}=0.4, p<0.05, n=79$ ), indicating that the percentage of fallow land in total cropland was proportional to the percentage of cropland in total landscape. A more mixed and random pattern was observed during the subsequent recession period (2006-2015) when the relationship between the two variables was non-significant. This means that the proportion of fallow land changed over time irrespective of the total stock of cropland at landscape scale; such a pattern can be seen as a result of the progressive reduction in subsidies to set aside. The share of fallow land receiving subsidies in total fallow land (2015) increased in areas less specialized in agriculture (e.g., Oropos in Northern Attica), or more exposed to urban expansion (e.g., Acharnes in the Greater Athens' area, Salamina Island, and Messoghia district in Eastern Attica), being considerably lower in areas traditionally devoted to specialized cropland with high economic value and less affected by urban sprawl (e.g., Megara in Western Attica, Marathon in Eastern Attica). In such context, our findings suggest that fallow land may acted as an additional land stock. In the case of Athens, an increasing proportion of land was destined to crop production during crisis, mainly tree crop.
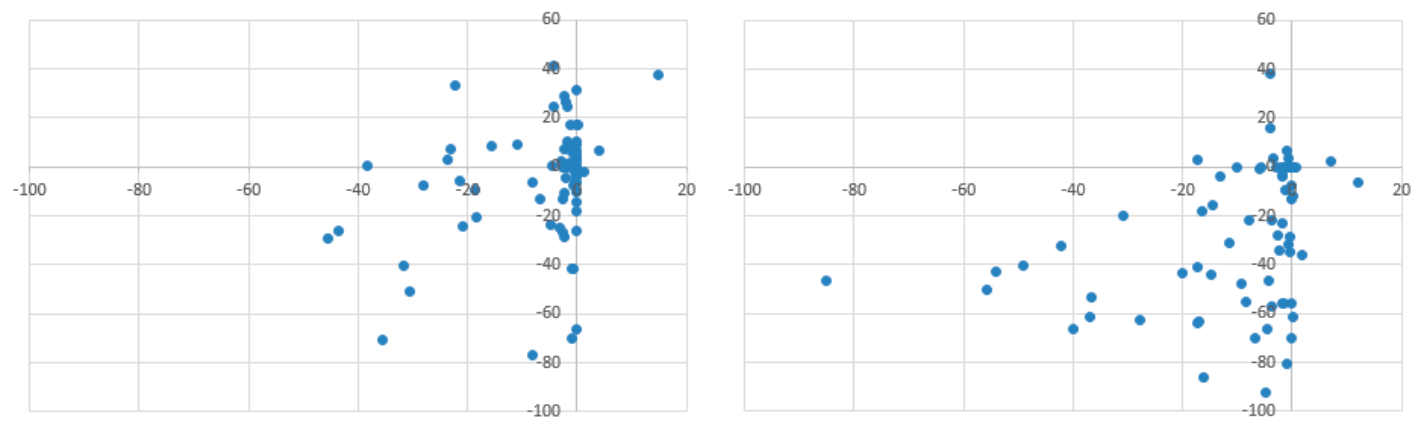

Figure 3. Relationship between percent change in cropland (y-axis) and fallow land (x-axis) in each municipality of the study area with at least 0.1 ha cropland in 1993 (left: 1993-2006; right: 2006-2015).

\subsection{Results of a Two-Way Clustering}

A specific analysis of processes of convergence (or divergence) over time between total cropland and fallow land in total landscape was based on a two-way clustering (Figure 4) that explores spatial trends of both variables at three time points $(1993,2006,2015)$ over the study area. The same color in Figure 4 indicate a similar pattern between variables, characterized by values respectively below the average (green) or above the average (red). Fallow land in 2015 displays a divergent distribution in respect with the same variable in previous time points (1993 and 2006). These results confirm the empirical findings described in Section 3.2. Fringe municipalities surrounding central Athens clustered at the top of the graph and were characterized by low standardized values $(<-1)$ of the share of cropland in total landscape. More mixed clusters of municipalities were observed in rural Attica, where similar variables' ranks were observed for land-use indicators at 1993 and 2006 and dissimilar ranks between total cropland and fallow land were recorded for 2015. In other words, two-way clustering ordered spatial units along the urban-rural gradient in Athens, evidencing a strong similarity among peri-urban municipalities and a more mixed pattern for rural municipalities. 


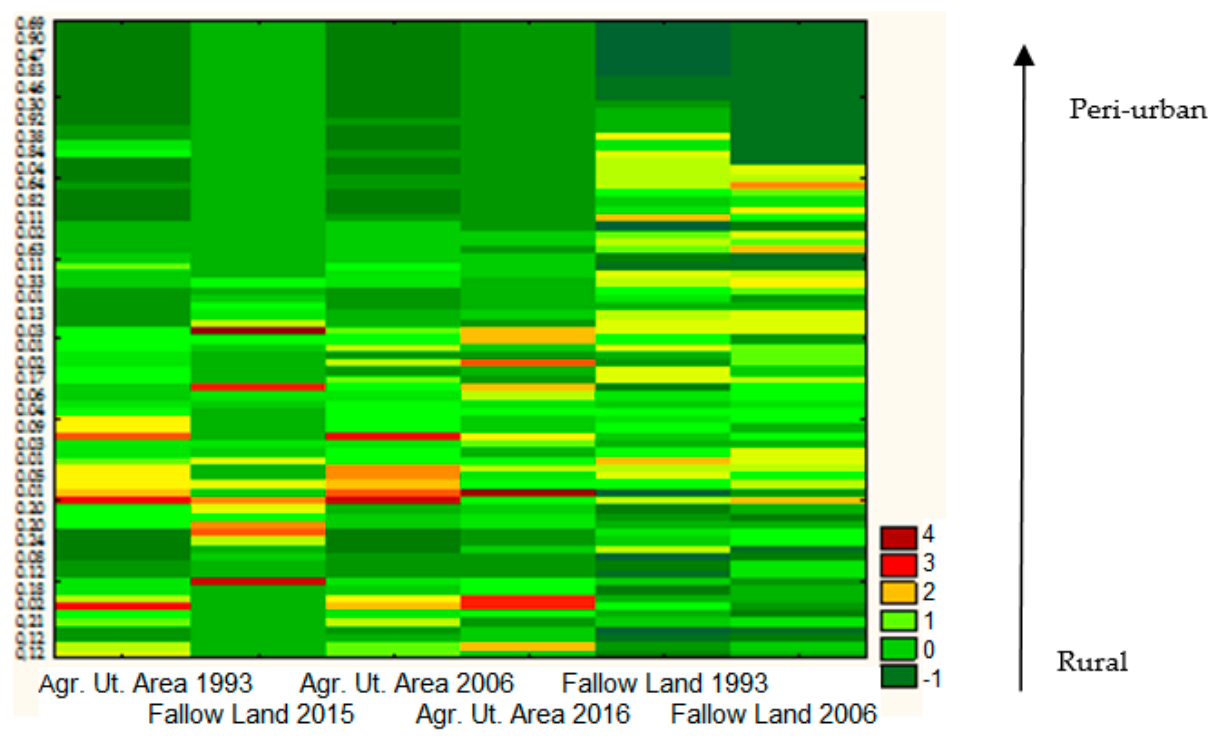

Figure 4. Results of two-way clustering by land-use indicators (columns) and municipalities (rows); the left rank indicates the share of built-up areas in total landscape for each municipality of the study area (colors illustrate the standardized value for each variable according to the legend on the right side of the graph).

\subsection{Spearman Rank Correlation Analysis}

Pair-wise correlations between land-use indicators and background variables were studied through a Spearman non-parametric analysis (Table 2) with the aim to identify the most relevant socio-demographic factors associated with a progressive decline of total cropland and fallow land over time. Total cropland decreased significantly with population density and increased with the distance from Athens, Piraeus, Maroussi, and with the proportion of workers living and working in the same municipality. A stable correlation profile was observed for the three study years. Additionally, total cropland increased with per-capita built-up area and decreased with per-capita declared income in 2015. In line with the spatial pattern observed for total cropland, fallow land decreased with population density for all years examined. A more specific correlation pattern was observed for 2015, when fallow land increased with forest land, per-capita built-up area, and distance from Athens and Maroussi. This pattern indicates that, after a crisis, fallow land concentrated in more remote, rural districts, where land profitability is lower; in more accessible rural districts fallow land declined rapidly during recession, irrespective of cropland decline; in such areas fallow land was more likely cultivated during a crisis, thanks to higher land profitability and the overall reduction of subsidies. Such dynamics may also reflect the intrinsic decrease in building activity in the last decade and the reduced pressure of land speculation associated with a negative peak in the real estate market. The share of subsidized fallow land in total fallow land decreased with the distance from Messoghia and with residential mobility (an indicator of urban expansion typically higher in Eastern Attica than in Western Attica), increasing significantly with per-capita declared income and the share of the non-Greek population native to Europe in the total resident population. 
Table 2. Results of a Spearman rank correlation analysis (significant coefficients at $p<0.05$ were shown).

\begin{tabular}{|c|c|c|c|c|c|c|c|}
\hline \multirow[t]{2}{*}{ Variable } & \multicolumn{3}{|c|}{$\begin{array}{c}\text { Utilized } \\
\text { Agricultural Area }\end{array}$} & \multicolumn{3}{|c|}{$\begin{array}{l}\text { Fallow Land } \\
\text { in Total Cropland }\end{array}$} & \multirow{2}{*}{$\begin{array}{c}\text { Subsidized Land } \\
\text { In Total } \\
\text { Fallow Land }\end{array}$} \\
\hline & 1993 & 2006 & 2015 & 1993 & 2006 & 2015 & \\
\hline Population density & -0.60 & -0.67 & -0.74 & -0.42 & -0.47 & -0.49 & \\
\hline Forests in total landscape & & & & & & 0.44 & \\
\hline Per-capita built-up area & & & 0.74 & & 0.48 & 0.46 & \\
\hline Distance from Athens & 0.53 & 0.64 & 0.69 & & & 0.43 & \\
\hline Distance from Piraeus & 0.50 & 0.60 & 0.64 & & & & \\
\hline Distance from Maroussi & & 0.50 & 0.57 & & & 0.42 & \\
\hline Distance from Markopoulo Me. & & & & & & & -0.65 \\
\hline Municipal area & & 0.46 & 0.56 & & & 0.52 & \\
\hline Per-capita declared income $(\log )$ & & & -0.45 & & & & 0.65 \\
\hline Self-contained workers & 0.50 & 0.51 & 0.59 & & & & \\
\hline Self-contained population & & & & & & & -0.60 \\
\hline Per cent rate of non-native population born in Europe & & & & & & & 0.61 \\
\hline
\end{tabular}

\section{Discussion}

Landscape transformations were more intense in local contexts where resident population increased rapidly because of suburbanization and where ecosystems are more fragile due to specific land conditions [31,37-51]. Attica's landscape experienced soil consumption and changes in rural areas producing negative environmental externalities [52]. With economic crisis, a small, but increasing, number of residents in Greek cities (especially in Athens and Salonika) declared the willingness to leave their city with the aim to work in the agricultural sector $[29,53,54]$. Moreover, an earlier study on farmers' multiple activities in peri-urban districts of Attica stated that $40 \%$ of the household members who are of working age have declared to have two or more jobs, because peri-urban districts surrounding central cities offer more opportunities for alternative jobs than strictly rural areas [53].

The empirical analysis carried out in this study contributes to distinguish the most urbanized contexts close to the Greater Athens' area from the rest of the metropolitan region. Athens has experienced one of the most rapid expansions of resident population, income, and settlements in Southern Europe [31,32,53]. A trend toward discontinuous urban expansion was observed since the 1980s [55,56], with a prevalence of medium-low density settlements expanding along the sea coastline and in Messoghia district (Eastern Attica), following suburbanization processes [18,22,57]. With recent changes in the Athens' socioeconomic context, building activity declined markedly since the 2007 financial crisis [58].

The inherent modifications of the rural landscape in metropolitan Attica are strongly associated with the local socio-demographic context, possibly reflecting sequential cycles of economic growth and crisis. Fallow land was demonstrated to be a relevant element of this transforming landscape, being relatively stable over time in Attica. During economic expansion, fallow land increased moderately or remained stable, despite a progressive decline in total cropland at the municipal scale. Together with other socioeconomic reasons, this pattern can be associated with the EU subsidy regime of direct payment to set-aside. In such a context, fallow land concentrated in fringe districts surrounding the Greater Athens' area, where agriculture competed more strongly with urban expansion.

During crises, fallow land decreased in more accessible rural areas coinciding with an inherent reduction in direct subsidies to farmers. In these areas, fallow land was sometimes converted to more productive crops, including vines and olives, as the official statistics at an aggregate spatial scale may indicate. This transition occurred in spite of strong accessibility to downtown Athens and high land prices-in many cases associated with a context of planning deregulation and ineffective/partial land cadaster. A marked decline in building activity and real estate speculation driven by recession was considered an indirect factor leading to productive transformations of rural landscapes that contain land conversion to urban use. While being directly affected by changes in the subsidy regime, results of 
this study suggest that both increasing tree crops and decreasing fallow land are indirectly associated with this building trend.

Considering the distinct dynamics that have characterized landscape transformations in Attica during the last economic expansions and recessions, fallow land was hypothesized to act as a land stock in the most recent decade, being available to both agricultural production and real estate speculation depending on economic downturns, planning flexibility and the specific subsidy regime. During economic expansion, fallow land increased thanks to direct payment to set-aside. At the same time, when building activity and land speculation were the highest, fallow land consolidated as a land stock, with some owners waiting for land zoning revisions-a frequent process in Greece, at least up to the early 2000s. Latent factors, such as poor effectiveness of town planning and expansion of unauthorized, and often illegal, buildings converted to legal settlements before political elections, contributed to this process. Conversely, fallow land in 2015 concentrated in less accessible, forest and upland districts further away from Athens. Under a progressively reduced subsidy regime, these districts were characterized together by slight increase in building activity and real estate speculation (possibly thanks to planned gains in road accessibility to Athens) and relatively low agricultural productivity. This specific pattern was confirmed by the spatial distribution of fallow land receiving subsidies in 2015, which was totally independent from the spatial distribution of fallow land in total cropland. Fallow land under subsidies hence concentrated in areas more exposed to real-estate speculation (e.g., Eastern Attica), while decreasing significantly in areas more specialized in agriculture (e.g., Western Attica), where land profitability is higher. Agro-environmental measures promoting more sustainable cropping systems may also contribute to this spatial pattern, being more relevant in rural areas with less intensive agriculture.

Together with cropland decline, the share of irrigated land in total cultivated land showed a small increase in rural Attica (from 8.8\% to 13.1\%), compared with the slight decline observed in the Greater Athens' area (from 3.9\% to 1.7\%) [29,59-61]. This evidence outlines, at least for the last decade, an increasing polarization in economically-marginal rural land (with high rate of cropland abandonment, forestation, moderate human pressure, and urban sprawl) and highly-productive agricultural districts (with decreasing proportion of fallow land, stable cropland, a more intense conversion to tree crop systems, and reduced land speculation for alternative uses of land-including conversion to urban destinations). These findings are in line with more general transformations of rural landscapes recently observed in Attica and in other Mediterranean urban regions [62-65], including local-scale processes of agricultural intensification (increase in vineyards and garden crops and consequent decrease in arable land) or extensivation (expansion of tree crops, mainly olive groves). For instance, it was demonstrated how olive groves may buffer human pressure in peri-urban areas, contributing to ecological stability through soil protection and high-quality water conservation [42,50,66-70]. Urban growth, rural development, new attitudes of farmers through irrigation, intensification, and mechanization, as well as more latent effects linked with the disappearance of full-time farmers and large-size farms, have contributed to shape the rural landscape around cities, with marginal land being more influenced by sequential cycles of economic expansion and recession [71]. In these regards, economic instability contributes to the inherent differences between peri-urban landscapes with intense industrialization and compact urbanization and mixed rural landscapes with resilient "cultivation patches", involving inevitable trade-offs among land profitability and rural identity [72].

Results of this study outline a sort of landscape "co-evolution" between urban expansion, economic cycles and peri-urban farming systems. Understanding how countryside cohabits with other uses of land along urban fringes is necessary since the current landscape can be recognized as an "agriburbia", where agricultural production is mixed with other uses [73,74]. Multifaceted processes underlying such co-evolution have been observed in the study area over the last decades, leading urban and rural elements to coexist [53]. In these regards, fallow land is supposed to be a landscape element sensitive to the latent interplay between economy, society and environment. Further investigation is 
required to ascertain the role of fallow land as (i) a reserve of value for building purposes thanks to real estate speculation, and (ii) as a land stock available for more profitable cultivations, determining agricultural intensification of fringe districts.

Central and local governments are requested to develop land-use plans incorporating measures for stabilization of marginal land, intended as a proxy of sustainable agriculture, natural conservation and preservation of typical cropping systems [42,44,68,75-83]. Our results suggest that direct subsidies to fallow land are a key part of this strategy at least up to 2006. In the last decade, the spatial distribution of land under subsidies was substantially different from the distribution of total fallow land at both local and regional scale. In this renewed context-with the progressive reduction of direct payments to set-aside-subsidies indirectly promoted stability of fallow land only in some areas, e.g., preventing conversion to alternative agricultural use of land in rural marginal areas, while consolidating pressures for land speculation and conversion to urban use in peri-urban districts.

\section{Conclusions}

Spatio-temporal trends of total cropland and fallow land—and especially the most recent dynamics under recession-may reflect resilience and adaptability of Mediterranean peri-urban landscapes to changing socio-demographic conditions [17]. Under the assumption that soil deterioration and manipulation of rural landscapes result from various kinds of land mismanagement, preserving marginal land from both soil degradation - a particularly acute environmental process in Southern Europe-and physical loss (e.g., conversion to urban use) is an important issue for any strategy of rural development. In line with a generalized expansion of forests and shrubland and the contemporary loss of farmland in several European regions, promoting the expansion of agroforestry systems with multiple use of the land to develop tourism, wildlife, hunting and sports, is an effective measure contributing to maintain ecological potential and cultural traditions associated with landscapes dominated by fallow land. These opportunities can be combined with extensive grazing and timber production. Based on this framework, territorial variability, topographic complexity and urbanization-driven land fragmentation are a relevant challenge for politicians, policy makers and land managers [44,84-91]. Under the assumption that regional transformations impact (positively or negatively) local socioeconomic systems, the resulting environmental conditions required extensive monitoring and coherent policy interventions from a socio-ecological perspective. In this line of thinking, landscape transformations can be more effectively governed by multi-level policies reconnecting short-term and long-term socioeconomic targets, managing together economic downturns and structural change.

Author Contributions: P.S. and R.S. conceived and designed the experiments; L.S. and R.S. analyzed the data; and I.Z. and L.S. wrote the paper.

Funding: This research received no external funding.

Conflicts of Interest: The authors declare no conflict of interest.

\section{References}

1. Nuissl, H.; Haase, D.; Lanzendorf, M.; Wittmer, H. Environmental impact assessment of urban land use transitions-A context-sensitive approach. Land Use Policy 2009, 26, 414-424. [CrossRef]

2. Wu, K.Y.; Zhang, H. Land use dynamics, built-up land expansion patterns, and driving forces analysis of the fast-growing Hangzhou metropolitan area, eastern China (1978-2008). Appl. Geogr. 2012, 34, 137-145. [CrossRef]

3. Boubaker, K.; Colantoni, A.; Marucci, A.; Longo, L.; Gambella, F.; Cividino, S.; Cecchini, M. Perspective and potential of $\mathrm{CO}_{2}$ : A focus on potentials for renewable energy conversion in the Mediterranean basin. Renew. Energy 2016, 90, 248-256. [CrossRef] 
4. Delfanti, L.; Colantoni, A.; Recanatesi, F.; Bencardino, M.; Sateriano, A.; Zambon, I.; Salvati, L. Solar plants, environmental degradation and local socioeconomic contexts: A case study in a Mediterranean country. EIA Rev. 2016, 61, 88-93. [CrossRef]

5. Colantoni, A.; Allegrini, E.; Boubaker, K.; Longo, L.; Di Giacinto, S.; Biondi, P. New insights for renewable energy hybrid photovoltaic/wind installations in Tunisia through a mathematical model. Energy Convers. Manag. 2013, 75, 398-401. [CrossRef]

6. Marucci, A.; Zambon, I.; Colantoni, A.; Monarca, D. A combination of agricultural and energy purposes: Evaluation of a prototype of photovoltaic greenhouse tunnel. Renew. Sustain. Energy Rev. 2018, 82, 1178-1186. [CrossRef]

7. Marucci, A.; Colantoni, A.; Zambon, I.; Egidi, G. Precision farming in hilly areas: The use of network RTK in GNSS technology. Agriculture 2017, 7, 60. [CrossRef]

8. Zambon, I.; Monarca, D.; Cecchini, M.; Bedini, R.; Longo, L.; Romagnoli, M.; Marucci, A. Alternative energy and the development of local rural contexts: An approach to improve the degree of smart cities in the Central-Southern Italy. Contemp. Eng. Sci. 2016, 9, 1371-1386. [CrossRef]

9. Estel, S.; Kuemmerle, T.; Alcántara, C.; Levers, C.; Prishchepov, A.; Hostert, P. Mapping farmland abandonment and recultivation across Europe using MODIS NDVI time series. Remote. Sens. Environ. 2015, 163, 312-325. [CrossRef]

10. Kuemmerle, T.; Erb, K.; Meyfroidt, P.; Müller, D.; Verburg, P.H.; Estel, S.; Levers, C. Challenges and opportunities in mapping land use intensity globally. Curr. Opin. Environ. Sustain. 2015, 5, 484-493. [CrossRef] [PubMed]

11. Primdahl, J.; Peco, B.; Schramek, J.; Andersen, E.; Oñate, J.J. Environmental effects of agri-environmental schemes in Western Europe. J. Environ. Manag. 2003, 67, 129-138. [CrossRef]

12. Colantoni, A.; Ferrara, C.; Perini, L.; Salvati, L. Assessing Trends in Climate Aridity and Vulnerability to Soil Degradation in Italy. Ecol. Indic. 2015, 48, 599-604. [CrossRef]

13. Tanrivermis, H. Agricultural land use change and sustainable use of land resources in the Mediterranean region of Turkey. J. Arid. Environ. 2003, 54, 553-564. [CrossRef]

14. Garcia Latorre, J.; Garcia-Latorre, J.; Sanchez-Picon, A. Dealing with aridity: Socio-economic structures and environmental changes in an arid Mediterranean region. Land Use Policy 2001, 18, 53-64. [CrossRef]

15. Schneider, A.; Woodcock, C.E. Compact, dispersed, fragmented, extensive? A comparison of urban growth in twenty-five global cities using remotely sensed data, pattern metrics and census information. Urban Stud. 2008, 45, 659-692. [CrossRef]

16. Colantoni, A.; Grigoriadis, E.; Sateriano, A.; Venanzoni, G.; Salvati, L. Cities as selective land predators? A lesson on urban growth, deregulated planning and sprawl containment. Sci. Total. Environ. 2016, 545, 329-339. [CrossRef] [PubMed]

17. Ceccarelli, T.; Bajocco, S.; Perini, L.; Salvati, L. Urbanisation and Land Take of High Quality Agricultural Soils-Exploring Long-term Land Use Changes and Land Capability in Northern Italy. Int. J. Environ. Res. 2014, 8, 181-192.

18. Arapoglou, V.P.; Sayas, J. New facets of urban segregation in southern Europe. Eur. Urban Reg. Stud. 2009, 16, 345-362. [CrossRef]

19. Di Feliciantonio, C.; Salvati, L. 'Southern' alternatives of urban diffusion: Investigating settlement characteristics and socioeconomic patterns in three Mediterranean regions. Tijdschr. Econ. Soc. Geogr. 2015, 106, 453-470. [CrossRef]

20. Maloutas, T. Segregation and residential mobility: Spatially entrapped social mobility and its impact on segregation in Athens. Eur. Urban Reg. Stud. 2004, 11, 195-211. [CrossRef]

21. Carlucci, M.; Grigoriadis, E.; Rontos, K.; Salvati, L. Revisiting an Hegemonic Concept: Long-term 'Mediterranean Urbanization' in between city re-polarization and metropolitan decline. Appl. Spat. Anal. Policy 2017, 10, 347-362. [CrossRef]

22. Chorianopoulos, I.; Pagonis, T.; Koukoulas, S.; Drymoniti, S. Planning, competitiveness and sprawl in the Mediterranean city: The case of Athens. Cities 2010, 27, 249-259. [CrossRef]

23. Chorianopoulos, I.; Tsilimigkas, G.; Koukoulas, S.; Balatsos, T. The shift to competitiveness and a new phase of sprawl in the Mediterranean city: Enterprises guiding growth in Messoghia-Athens. Cities 2014, 39, 133-143. [CrossRef] 
24. Rontos, K.; Grigoriadis, E.; Sateriano, A.; Syrmali, M.; Vavouras, I.; Salvati, L. Lost in protest, found in segregation: Divided cities in the light of the 2015 "O $\chi \iota^{\prime \prime}$ referendum in Greece. City Cult. Soc. 2016, 7, 139-148. [CrossRef]

25. Souliotis, N. Cultural economy, sovereign debt crisis and the importance of local contexts: The case of Athens. Cities 2013, 33, 61-68. [CrossRef]

26. Zitti, M.; Ferrara, C.; Perini, L.; Carlucci, M.; Salvati, L. Long-term urban growth and land use efficiency in Southern Europe: Implications for sustainable land management. Sustainability 2015, 7, 3359-3385. [CrossRef]

27. Gospodini, A. Portraying, classifying and understanding the emerging landscapes in the post-industrial city. Cities 2006, 23, 311-330. [CrossRef]

28. European Environment Agency. Mapping Guide for a European Urban Atlas. Copenhagen. Available online: http:/ / www.eea.europa.eu/data-and-maps/data/urban-atlas (accessed on 11 December 2017).

29. Cecchini, M.; Zambon, I.; Pontrandolfi, A.; Turco, R.; Colantoni, A.; Mavrakis, A.; Salvati, L. Urban Sprawl and the 'olive'landscape: Sustainable land management for 'crisis' cities. GeoJournal 2018, 1-19.

30. Zambon, I.; Sauri, D.; Serra, P.; Carlucci, M.; Salvati, L. Beyond the 'Mediterranean city': Socioeconomic disparities and urban sprawl in three Southern European cities. Geogr. Ann. Ser. B Hum. Geogr. 2017, 99, 319-337. [CrossRef]

31. Gargiulo, M.V.; Rontos, K.; Salvati, L. Between suburbanisation and re-urbanisation? Revisiting the Urban Life Cycle in a Mediterranean Compact City. Urban Res. Pract. 2014, 7, 74-88.

32. Kallis, G. Co-evolution in water resource development. The vicious cycle of water supply and demand in Athens, Greece. Ecol. Econ. 2010, 69, 796-809. [CrossRef]

33. Kaika, M. The economic crisis seen from the everyday. City 2012, 16, 422-430. [CrossRef]

34. De Rosa, S.; Salvati, L. Beyond a 'side street story'? Naples from spontaneous centrality to entropic polycentricism, towards a 'crisis city'. Cities 2016, 51, 74-83. [CrossRef]

35. Gkartzios, M.; Remoundou, K.; Garrod, G. Emerging geographies of mobility: The role of regional towns in Greece's 'counterurbanisation story'. J. Rural. Stud. 2017, 55, 22-32. [CrossRef]

36. Gkartzios, M.; Scott, K. A Cultural Panic in the Province? Counterurban Mobilities, Creativity, and Crisis in Greece. Popul. Space Place 2015, 21, 843-855. [CrossRef]

37. Aretano, R.; Petrosillo, I.; Zaccarelli, N.; Semeraro, T.; Zurlini, G. People perception of landscape change effects on ecosystem services in small Mediterranean islands: A combination of subjective and objective assessments. Landsc. Urban Plan. 2013, 112, 63-73. [CrossRef]

38. Beriatos, E.; Gospodini, A. Glocalising urban landscapes: Athens and the 2004 Olympics. Cities 2004, 21, 187-202. [CrossRef]

39. Biasi, R.; Brunori, E.; Smiraglia, D.; Salvati, L. Linking traditional tree-crop landscapes and agro-biodiversity in Central Italy using a database of typical and traditional products: A multiple risk assessment through a data mining analysis. Biodivers. Conserv. 2015, 24, 3009-3031. [CrossRef]

40. Biasi, R.; Colantoni, A.; Ferrara, C.; Ranalli, F.; Salvati, L. In-between Sprawl and Fires: Long-term Forest Expansion and Settlement Dynamics at the Wildland-Urban Interface in Rome, Italy. Int. J. Sustain. Dev. World Ecol. 2015, 22, 467-475. [CrossRef]

41. Cimini, D.; Tomao, A.; Mattioli, W.; Barbati, A.; Corona, P. Assessing impact of forest cover change dynamics on high nature value farmland in Mediterranean mountain landscape. Ann. Silvic. Res. 2013, 37, $29-37$.

42. Cohen, M.; Bilodeau, C.; Alexandre, F.; Godron, M.; Andrieu, J.; Gresillon, E.; Garlatti, F.; Morganti, A. What is the plant biodiversity in a cultural landscape? A comparative, multi-scale and interdisciplinary study in olive groves and vineyards (Mediterranean France). Agric. Ecosyst. Environ. 2015, 212, 175-186. [CrossRef]

43. Economidou, E. The Attic landscape throughout the centuries and its human degradation. Landsc. Urban Plan. 1993, 24, 33-37. [CrossRef]

44. Kizos, T.; Vakoufaris, H. Valorisation of local asset: The case of olive oil on Lesvos Island, Greece. Food Policy 2011, 36, 705-714. [CrossRef]

45. Kristensen, S.P.; Thenail, C.; Kristensen, L. Farmers' involvement in landscape: An analysis of the relationship between farm location, farm characteristics and landscape changes in two study areas in Jutlund, Denmark. J. Environ. Manag. 2001, 61, 301-318. [CrossRef] [PubMed]

46. Raudsepp-Hearne, C.; Peterson, G.D.; Bennett, E.M. Ecosystem service bundles for analyzing tradeoffs in diverse landscapes. Proc. Natl. Acad. Sci. USA 2010, 107, 5242-5247. [CrossRef] [PubMed] 
47. Salvati, L. Agro-forest landscape and the 'fringe' city: A multivariate assessment of land-use changes in a sprawling region and implications for planning. Sci. Total. Environ. 2014, 490, 715-723. [CrossRef] [PubMed]

48. Serra, P.; Pons, X.; Saurì, D. Land-cover and land-use change in a Mediterranean landscape: A spatial analysis of driving forces integrating biophysical and human factors. Appl. Geogr. 2008, 28, 189-209. [CrossRef]

49. Tsilimigkas, G.; Kizos, T. Space, pressures and the management of the Greek landscape. Geogr. Ann. Ser. B Hum. Geogr. 2014, 96, 159-175. [CrossRef]

50. Vieri, M. Traditional olive crop mechanization in areas with a high landscape value. Results of tests with new olive picking equipment. Adv. Hortic. Sci. 2002, 16, 235-239.

51. Zambon, I.; Ferrara, A.; Salvia, R.; Mosconi, E.M.; Fici, L.; Turco, R.; Salvati, L. Rural Districts between Urbanization and Land Abandonment: Undermining Long-Term Changes in Mediterranean Landscapes. Sustainability 2018, 10, 1159. [CrossRef]

52. Orsini, S. Landscape polarisation, hobby farmers and valuable hills in Tuscany: Understanding landscape dynamics in a peri-urban context. Geogr. Tidsskr. Dan. J. Geogr. 2013, 113, 54-64. [CrossRef]

53. Moissidis, A.; Duquenne, M.-N. Peri-urban rural areas in Greece: The case of Attica. Sociol. Rural. 1997, 37, 228-239. [CrossRef]

54. Gkartzios, M. 'Leaving Athens': Narratives of counterurbanisation in times of crisis. J. Rural. Stud. 2013, 32, 158-167. [CrossRef]

55. Delladetsima, P.M. The emerging property development pattern in Greece and its impact on spatial development. Eur. Urban Reg. Stud. 2006, 13, 245-278. [CrossRef]

56. Giannakourou, G. Planning regulation, property protection, and regulatory takings in the Greek planning law. Wash. Univ. Glob. Stud. Law Rev. 2006, 5, 534-557.

57. Cuadrado-Ciuraneta, S.; Durà-Guimerà, A.; Salvati, L. Not only tourism: Unravelling suburbanization, second-home expansion and "rural" sprawl in Catalonia, Spain. Urban Geogr. 2017, 38, 66-89. [CrossRef]

58. Serra, P.; Vera, A.; Tulla, A.F.; Salvati, L. Beyond urban-rural dichotomy: Exploring socioeconomic and land-use processes of change in Spain (1991-2011). Appl. Geogr. 2014, 55, 71-81. [CrossRef]

59. Almeida, A.; Figueiredo, T.; Fernandes-Silva, A. Evolution of factors affecting mechanical olive harvesting. Acta Hortic. 2016, 1139, 575-579. [CrossRef]

60. Calabrese, G.; Tartaglini, N.; Ladisa, G. Study on Biodiversity in Century-Old Olive Groves; CIHEAM-Mediterranean Agronomic Institute: Bari, Italy, 2012.

61. Famiani, F.; Farinelli, D.; Rollo, S.; Camposeo, S.; Di Vaio, C.; Inglese, P. Evaluation of different mechanical fruit harvesting systems and oil quality in very large size olive trees. Span. J. Agric. Res. 2014, 12, 960-997. [CrossRef]

62. Gutierrez, A.P.; Ponti, L.; Cossu, Q.A. Effects of climate warming on Olive and olive fly (Bactrocera oleae Gmelin) in California and Italy. Clim. Chang. 2009, 95, 195-217. [CrossRef]

63. Kizos, T. Multifunctionality of farm households in Greece. Nor. Geogr. Tidsskr. Nor. J. Geogr. 2010, 64, $105-116$. [CrossRef]

64. Kizos, T.; Vasdeki, M.; Chatzikiriakou, C.; Dimitriou, D. 'For my children': Different functions of the agricultural landscape and attitudes of farmers on different areas of Greece towards small scale landscape change. Geogr. Tidsskr. Dan. J. Geogr. 2011, 111, 117-130. [CrossRef]

65. Loumou, A.; Giourga, C. Olive groves: 'The life and identity of Mediterranean'. Agric. Hum. Values 2003, 20, 87-95. [CrossRef]

66. Meneley, A. Extra Virgin Olive Oil and Slow Food. Anthropologica 2004, 46, 165-176. [CrossRef]

67. Palazzo, A.L.; Aristone, O. Peri-Urban Matters. Changing Olive Growing Patterns in Central Italy. Sustainability 2017, 9, 638. [CrossRef]

68. Tanasijevic, L.; Todorovic, M.; Pereira, L.S.; Pizzigalli, C.; Lionello, P. Impacts of climate change on olive crop evapotranspiration and irrigation requirements in the Mediterranean region. Agric. Water Manag. 2014, 144, 54-68. [CrossRef]

69. Makhzoumi, J.M. The changing role of rural landscapes: Olive and carob multi-use tree plantations in the semiarid Mediterranean. Landsc. Urban Plan. 1997, 37, 115-122. [CrossRef]

70. Paetzold, A.; Warren, P.H.; Maltby, L.L. A framework for assessing ecological quality based on ecosystem services. Ecol. Complex. 2010, 7, 273-281. [CrossRef] 
71. Duvernoy, I.; Zambon, I.; Sateriano, A.; Salvati, L. Pictures from the Other Side of the Fringe: Urban Growth and Peri-urban Agriculture in a Post-industrial City (Toulouse, France). J. Rural. Stud. 2018, 57, 25-35. [CrossRef]

72. Newman, L.; Powell, L.J.; Nickel, J.; Anderson, D.; Jovanovic, L.; Mendez, E.; Kelly-Freiberg, K. Farm stores in agriburbia: The roles of agricultural retail on the rural-urban fringe. Canadian Food Studies/La Revue Canadienne des Études sur L'alimentation 2017, 4, 4-23. [CrossRef]

73. Sandul, P.J. The agriburb: Recalling the suburban side of ontario, california's agricultural colonization. Agric. Hist. 2010, 84, 195-223. [CrossRef] [PubMed]

74. Le Houérou, H.N. Land degradation in Mediterranean Europe: Can agroforestry be a part of the solution? A prospective review. Agrofor. Syst. 1993, 21, 43-61. [CrossRef]

75. Brunori, E.; Farina, R.; Biasi, R. Sustainable viticulture: The carbon-sink function of the vineyard agro-ecosystem. Agric. Ecosyst. Environ. 2016, 223, 10-21. [CrossRef]

76. Giourga, C.; Loumou, A. Assessing the impact of pluriactivity on sustainable agriculture. A case study in rural areas of Beotia in Greece. Environ. Manag. 2006, 37, 753-763. [CrossRef] [PubMed]

77. Monarca, D.; Cecchini, M.; Colantoni, A.; Di Giacinto, S.; Menghini, G.; Longo, L. Study on the possibility of application of a compact roll over protective structure for agricultural wheeled narrow track tractors. J. Agric. Eng. 2013, 44, e136. [CrossRef]

78. Mousazadeh, H.; Keyhani, A.; Mobli, H.; Bardi, U.; El Asmar, T. Sustainability in agricultural mechanization: Assessment of a combined photovoltaic and electric multipurpose system for farmers. Sustainability 2009, 1, 1042-1068. [CrossRef]

79. Portnov, B.A.; Safriel, U.N. Combating desertification in the Negev: Dryland agriculture vs. dryland urbanization. J. Arid Environ. 2004, 56, 659-680. [CrossRef]

80. Savo, V.; Caneva, G.; McClatchey, W.; Reedy, D.; Salvati, L. Combining environmental factors and agriculturalists' observations of environmental changes in the traditional terrace system of the Amalfi Coast (Southern Italy). Ambio 2014, 43, 297-310. [CrossRef] [PubMed]

81. Colantoni, A.; Cecchini, M.; Monarca, D.; Bedini, R.; Riccioni, S. The risk of musculoskeletal disorders due to repetitive movements of upper limbs for workers employed in hazelnut sorting. J. Agric. Eng. Res. 2013, 44. [CrossRef]

82. Monarca, D.; Cecchini, M.; Colantoni, A.; Marucci, A. Feasibility of the electric energy production through gasification processes of biomass: Technical and economic aspects. In Proceedings of the International Conference on Computational Science and Its Applications, Santander, Spain, 20-23 June 2011; Springer: Berlin/Heidelberg, Germany, 2011; pp. 307-315.

83. Monarca, D.; Cecchini, M.; Guerrieri, M.; Colantoni, A. Conventional and alternative use of biomasses derived by hazelnut cultivation and processing. Acta Horticult. 2008, 845, 27-634. [CrossRef]

84. Amato, F.; Maimone, B.A.; Martellozzo, F.; Nolè, G.; Murgante, B. The Effects of Urban Policies on the Development of Urban Areas. Sustainability 2016, 8, 297. [CrossRef]

85. Amato, F.; Tonini, M.; Murgante, B.; Kanevski, M. Fuzzy definition of Rural Urban Interface: An application based on land use change scenarios in Portugal. Environ. Model. Softw. 2018, 104, 171-187. [CrossRef]

86. Aubry, R.J.; Abat, M.-H.; Ramamonjisoa, J.; Dabat, M.H.; Rakotoarisoa, J.; Rakotondraibe, J.; Rabeharisoa, L. Urban agriculture and land use in cities: An approach with multi-functionality and sustainsability concepts in the case of Antananarivo (Madagascar). Land Use Policy 2012, 29, 429-439. [CrossRef]

87. Audsley, E.; Pearn, K.R.; Simota, C.; Cojocaru, G.; Koutsidou, E.; Rounsevell, M.D.A.; Trnka, M.; Alexandrov, V. What can scenario modelling tell us aboutfuture European scale agricultural land use and what not? Environ. Sci. Policy 2006, 9, 148-162. [CrossRef]

88. Giannakourou, G. Transforming spatial planning policy in Mediterranean countries: Europeanization and domestic change. Eur. Plan. Stud. 2005, 13, 319-331. [CrossRef]

89. Kelly, C.; Ferrara, A.; Wilson, G.A.; Ripullone, F.; Nolè, A.; Harmer, N.; Salvati, L. Community resilience and land degradation in forest and shrubland socio-ecological systems: Evidence in Gorgoglione, Basilicata, Italy. Land Use Policy 2015, 46, 11-20. [CrossRef] 
90. Mosquera-Losada, M.R.; Santiago Freijanes, J.J.; Pisanelli, A.; Rois, M.; Smith, J.; den Herder, M.; Ferreiro Domínguez, N. Extent and Success of Current Policy Measures to Promote Agroforestry Across Europe; Agforward European Project Policy Report; Agforward: Cranfield, UK, 2012.

91. Paul, V.; Haslam Mckenzie, F. Peri-urban farmland conservation and development of alternative food networks: Insights from a case study area in metropolitan Barcelona (Catalonia, Spain). Land Use Policy 2013, 30, 94-105. [CrossRef]

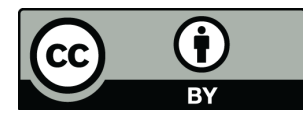

(C) 2018 by the authors. Licensee MDPI, Basel, Switzerland. This article is an open access article distributed under the terms and conditions of the Creative Commons Attribution (CC BY) license (http://creativecommons.org/licenses/by/4.0/). 